\title{
Family Formation: an Intergenerational Comparison Subtitlte: The Relevance of Social Inequalities for Family Formation in a Transnational Migration Context
}

\author{
Eveline Ammann Dula ${ }^{1}$ (D)
}

Published online: 25 August 2020

(C) The Author(s) 2020

\begin{abstract}
How do processes of family formation change over generations? What is the relevance of social inequalities for these processes and what kinds of strategies do family members develop to deal with them? Based on a case study of members of two generations from the same family using a biographical approach, we will demonstrate the diversity of family formation within one family. The article generates insights about the complexity of family formation processes, as previous research has shown that there is a fertility variation between and within migrant groups of different origins. The selected family is involved in a transnational migration process, originally from the former Yugoslavia, coming to Switzerland and then moving to Kosovo. Migration experiences started with the grandfathers' seasonal work migration. The family members were affected by social inequalities based on class, gender and ethnicity that are analysed using the concept of socio-cultural boundaries. The results illustrate the ways restrictions on access to the labour market, discrimination, educational institutions and selective migration regimes influence and shape family formation processes. It reveals that members of the same family develop diverse strategies to deal with exclusion and discrimination processes comparing their positions in transnational fields. We show how these family negotiation processes are interrelated with ethnicity and class and change over the generations. Furthermore, the analysis reveals that the transmission of gender norms in this family is influenced by the experienced socio-cultural boundaries. In sum, we show the complexity of family formation processes and intergenerational changes in interaction with intersectional social inequalities that are also shaped by migration policies.
\end{abstract}

Keywords Transnational families · Biographical research · Socio-cultural boundaries . Intergenerational transmission

Eveline Ammann Dula eveline.ammann@bfh.ch

1 Social Work Department, Bern University of Applied Sciences (BFH), Hallerstrasse 10, 3012 Bern, Switzerland 


\section{Introduction}

Based on biographical case studies of members of two generations of the same family, I illustrate how strategies of family formation change over generation and differentiate inside one family. This allows greater insights into the complexity of family formation processes, as previous research has shown that there is a fertility variation between and within migrant groups of different origins. The case study shows that within a minority group, and even within a single family, social inequalities can lead to different fertility behaviour.

The selected cases are part of a biographical analysis of one family from the former Yugoslavia. This family is involved in a transnational migration process leading them from their home village in southern Serbia to Switzerland and then to Kosovo. The family has been selected for the study of the transmission of migration experiences because its transnational migration processes have lasted over three generations ${ }^{1}$ (for the complete analysis cf. Ammann Dula 2019).

Persons from the former Yugoslavia were chosen as the object of investigation, as the former Yugoslavia has been linked to Switzerland since the 1960s through a long process of migration which has been described as a history of entanglement (Randeria and Römhild 2013, Ammann Dula 2019). Immigrants from the former Yugoslavia represent about a quarter of the foreign population in Switzerland and are the secondlargest group of immigrants after Italians (Schnell and Fibbi 2015). The analysis of the relevance of social inequalities and migration policies for persons from the former Yugoslavia on family formation is especially interesting, as each generation was affected by different migration policies. In the 1960s until the end of the 1980s, people from the former Yugoslavia came to Switzerland as guest workers. Former Yugoslavians were attractive to employers as a well-qualified but cheap labour force. However, labour migration between former Yugoslavia and Switzerland has been severely restricted since the $1990 \mathrm{~s}$, as Yugoslavia was classified as 'third country"2 (cf. Piguet 2006). Moreover, asylum migration ceased to be granted as of the end of the Kosovo War in 1999/2000. As the migration regime changed, so did the Swiss perception of the Kosovar population. Since the 1960s, the Kosovo Albanian population in Switzerland has increasingly faced negative prejudices and discrimination, for example, showing up in headlines about crimes and violence committed by 'Kosovo Albanians' in Swiss media (cf. Burri Sharani et al. 2010). Discrimination processes have also been identified as one reason why this population group is underrepresented in studies about employment rates or access to higher education of this population (cf. Fibbi et al., 2015). Previous studies indicate that ethnicity and gender are relevant for social boundary processes in Switzerland especially regarding immigrants from Kosovo, criminalising men and considering women as victims of patriarchal structures

\footnotetext{
${ }^{1}$ Based on the case analyses of the first theoretical sampling, the relevance of the intergenerational transmission of migratory experiences became evident and became the criterion for the second theoretical sampling (cf. Rosenthal 2011). Due to the transmission of migration experiences over three generations, this family was finally selected (cf. Ammann Dula 2019).

${ }^{2}$ Switzerland introduced the 'three-circle model' as new migration policy in 1991 (Piguet 2006: 71): the first circle includes states of the European Community (EC) and EFTA (free movement of persons). The second group includes the countries of the traditional recruitment areas outside the EC and EFTA, such as the USA and Canada (simplification of administrative processes). From all other countries (outermost circle), highly qualified specialists are only admitted in exceptional cases. Yugoslavia is included in the outermost circle (Piguet 2006).
} 
(Duemmler 2015). They are more than other minority groups affected by economic marginalisation, unemployment and a lower social status (Piquet 2006). For these reasons, the question of the significance of migration policies and social inequalities linked to ethnicity, gender and class for family formation seems particularly important for this population group.

To study social inequalities, the concept of socio-cultural boundaries (Amelina 2017 ) is used to explore the intersection of multiple dimensions of social inequalities such as gender, class and ethnicity that are produced, reproduced and transformed in macro-areas and within the family. Although researchers have taken into account social inequalities in transnational migration processes (cf. Mau 2007), only a few studies have integrated social inequalities when theorizing about migrant families and intergenerational transmission processes. Therefore, we will demonstrate the relevance of social inequalities for family formation in a transnational field. The biographical approach allows us not only to analyse the relevance of social inequalities for family formation but also to show the individual strategies developed by the different family members to deal with social inequalities.

The paper starts with an introduction of the theoretical concepts and methods used and will then present the relevance of social inequalities for family formation based on the result of the biographical analysis of members of one family from the former Yugoslavia. The comparison of family negotiation strategies of different family members allows to illustrate the complexity of family formation and highlights the diversity inside minority groups and the relevance of intersectional social inequalities.

\section{Theoretical Framework}

\section{Transnational Families}

The importance of the family has long been neglected in European migration studies and only became important in the 1990s (cf. Kofman, Kraler, Kohli and Schmoll 2011; Geisen 2014). The recognition of the importance of the family in migration studies coincides with the diversification of migration families in connection with changed national and European migration policies (Kofman et al. 2011). The nature of family migration has changed as marriage has become the primary means of entry and residence for third-country nationals in the EU (and Switzerland) due to restrictions on labour migration, especially for those without recognised skills (Kofman et al. 2011). Also, binational marriages, including persons with a native background and migrants entering for marriage, have increased steadily (Kofman et al. 2011). There is also an increase of skilled labour migration in several EU states. These migrants are often accompanied by family members. Furthermore, the temporality of migration changed. As in several countries, low-skilled migrants are increasingly admitted through temporary migration schemes and are often not entitled to family reunification (Kofman at al. 2001). As a result, people have completely different options for family formation, depending on their origin, nationality and recognised professional skills.

In the context of transnational migration research on family life, mobility plays an integral role, and thus the management of absence and distance is a central characteristic of transnational families (Baldassar and Merla 2014). The transnational perspective allows 
for the exploration of the diversity of families such as transnational parenthood and includes different meanings about kinship and relationships for families. This makes it possible in research to question the normative conception of (local) families within a nation-state and instead to explore social practices of families and their handling of challenges related to distance and separation (Baldassar and Merla 2014).

According to Baldassar and Merla (2014), the unique characteristic of transnational families is that their members are confronted with opportunities and challenges posed by the institutional conditions of at least two national states (and their respective migration policies) within a transnational and international context. Therefore, the relevance of considering the transnational context as entangled history becomes obvious. This raises the methodological challenge with respect to how social inequalities can be analysed in the context of transnational migration without resorting to essentialist concepts. Furthermore, several studies in migration research point to the importance of social inequalities in transnationalisation processes (e.g. Fouron and Glick Schiller 2001; Mau 2007).

\section{Social Inequalities in a Transnational Context}

The nation-state research framework, which was taken for granted in classical migration research for the analysis of social inequalities, is not suitable for the analysis of social inequalities of migrants who are operating in transnational fields. We can talk of a 'methodological nationalism' (cf. Wimmer and Glick Schiller 2002) that is presupposed in classical migration research. Overcoming this methodological nationalism requires a redefinition of the analytical frame to research social inequalities in the transnational migration context (Amelina 2012; Pries 2010). A further challenge is to include multiple social inequalities and their interplay in the investigation of transnational social inequalities (Amelina 2017). The categories of class and ethnicity have long been at the forefront of the analysis of social inequalities in migration research (Amelina 2012). This is particularly evident in classical assimilation studies where social inequality was conceived within a hierarchy of 'ethnic classes' in immigration countries (Amelina 2012). Furthermore, material inequalities were also at the centre of theories on social inequalities and in some studies that considered gender relations (Anthias 2001), neglecting other categories such as ethnicity or race. Other authors focused on the importance of gender in the analysis of transnational migration processes (cf. Fouron et al., 2001; Mahler and Pessar 2001; Apitzsch 2003), neglecting other categories such as ethnicity or class. Consequently, there is still a lack of studies acknowledging and conceptualising the multidimensionality of social inequalities in transnational migration studies. Therefore, we suggest using Amelina's (2017) analytical concept of socio-cultural boundaries to analyse the dynamic interdependence of different categories of social inequalities.

The disciplines of anthropology, history, political science, social psychology and sociology in the Anglo-Saxon research communities are using the concept of social boundaries as an analytical concept since the end of the 1990s (Lamont and Molnar 2002). In the social sciences, the conception of social processes of boundary-making is largely based on Lamont and Molnar (2002), who show the manifold uses of this analytical concept, as for example in relation to religion, cultural classifications, gender and sexuality, immigration or ethnicity and 'race' (Pachucki, Pendergrass and Lamont 
2007, cf. Duemmler 2015). Social boundaries are articulated by people in everyday interactions, using conceptual distinctions to construct notions of 'us' and 'them' (Duemmler et al., 2010). It focuses on the question of how these social boundaries in everyday interactions relate to social inequalities on a structural level (Pachucki et al. 2007). In this context, the characteristics of boundaries as well as the mechanisms of their activation, maintenance, change or dissolution are examined (Pachucki et al. 2007). The social boundary concept allows to reflect who carries out classifications, what purposes they serve and what effects they generate, and thus also enables the investigation of divisions and similarities within the various units (Anthias 2001).

Amelina further developed the concept of social boundaries as socio-cultural boundaries. The categorical distinctions are understood as intersubjectively shared and historically specific classifications which can be consciously or unconsciously, implicitly or explicitly and therefore conceptualised in a non-essentialist sense (Amelina 2017). These categorical distinctions, referred to by Amelina as cultural systems of classification, lead to hierarchized social positions, which manifest themselves in the form of unequal life chances and lead to an unequal distribution of estimated resources (ibid.). The conception of social inequalities as social boundary processes helps to overcome an essentialist understanding of categorical distinctions of social inequalities and to analyse instead how categorical distinctions are used by different actors like nation states, media or individuals in their daily interaction to produce or shift borderlines that can lead to social inequalities (Amelina 2012, Dahinden 2014). The term 'culture' for example serves no longer as explanans for differences and social inequalities but must be explained (Dahinden 2014). People 'make' culture and culture ultimately becomes an empirical question (ibid.). The decisive question is therefore perhaps not whether there are cultural differences, but in what political and socio-economic contexts 'culture' or other categories like gender or class etc. are used in everyday practices to justify or shape social inequalities. Therefore, the concept of socio-cultural boundaries allows one to analyse the links between structural and individual aspects of the production, reproduction and transformation of social inequalities.

Likewise, migration policies can be considered as a form of socio-cultural boundaries. The analysis of Dahinden (2014) argues, for example, that the culturalization and ethnicization of Swiss admissions policies along the national line denote as a form of boundary work, since it is here that 'foreigners' are defended against the outside and at the same time commonalities are created against the inside. In May 1991, the concept of 'cultural distance' between immigrants and the indigenous population was established by the Federal Council within the framework of the three-circle model (cf. p. 2). While the multicultural idea can be considered as an attempt to include 'cultural strangers' in the national community and extending established borderlines, the institutionalization of 'cultural distance' in Swiss migration law can be referred as a step towards a clear borderline between one's own and 'foreigners' (Dahinden 2014). The Foreigner Act of 2005 specifies the idea of 'cultural distance' and relates it with claims of integration: Immigrants from the EU/EFTA area are seen as capable of integration without reservations, whereas those from outside the EU are seen as burdened with deficiency. For people from outside the EU, integration has become a prerequisite for obtaining a settlement permit (Dahinden 2014). The actual situation of Albanians from former Yugoslavia in Switzerland, the experienced discrimination 
processes limiting their access to labour market and educational institutions (cf. Duemmler 2015), can also be considered as a form of socio-cultural boundary processes, linking the categories of class and ethnicity by preventing their social mobility.

As the processualism and openness for the analysis of the interaction between social inequalities and the actions of the actors are also at the forefront of biographical research, the socio-cultural boundary concept can be perfectly combined with the methodological approach of biographical research (cf. Ammann Dula 2018).

\section{Biographical Approach to Study Transnational Families}

Various studies use a biographical approach to the investigation of transnational migration processes (cf. Apitzsch 2003; Lutz 2004; Lutz and Schwalgin 2006; Siouti 2013 etc.), allowing to analyse the creation of transnational spaces in biographies (Ruokonen-Engler 2012) and to investigate the transnationalised meso- and macrostructures as biographical generating factors in narratives (Bauschke-Urban 2010). Reconstructive biographical research allows for the study of multiple affiliations and collective effects of different categories of social inequalities in biographical narratives employing a methodologically open approach (cf. Tuider 2011; Dausien 2008). The aim is to reconstruct the traces of the general social structure in individual biographies (Tuider 2011). This makes it possible to analyse intersectionality in multiple and partially colliding categories (ibid.). Moreover, the entanglement of the individual and societal levels in the biographical analysis also has the potential to reconstruct the interdependence of the various categories of social inequalities. This makes it possible to focus on the actors' strategies of action without neglecting social power structures. Lutz (2014) describes the application of an intersectional approach in biographical research as doing intersectionality, since the focus is on the actors as they negotiate their multiple affiliations within these structures in everyday life and thereby gain control over their lives. The structures of racism, class discrimination or sexism are not regarded as determining individual actions since categories such as gender or 'race' can also be used by actors to infiltrate or change practices of oppression (ibid.).

Existing studies have examined above all gendered biographical transmigration processes in a transnational migration context (see, e.g. Ruokonen-Engler 2012, Siouti 2013) and have shown how migrants are using 'transnational biographical capital as a central resource' (Siouti 2013). However, these studies were situated in a European context where selective migration regimes, restrictions on access to the labour market and educational institutions, did not have an important impact. In this case study, we demonstrate the interdependence not only of interwoven categories of social inequalities like class, ethnicity and gender for family formation but also the relevance of migration regimes.

The combination of the socio-cultural boundary approach offers an opportunity to link this interplay of processes of production, maintenance and change of social inequalities to the social and individual level and thus allows an intersectional analysis of social inequalities and to reveal its relevance for family formation in a transnational migration context.

The presented theoretical framework has been applied to the analysis of the biographical case studies of the different family members. After a biographical analysis of each of the seven family members following the reconstructive method of Rosenthal (2011), the relevance of the different categories that became obvious during the cases has been studied 
and compared. The relevance of gender, ethnicity and class and their interwovenness for the life courses was studied comparing the biographical cases of the seven family members. For example, the relevance of class was clear in the narrative of the father, justifying the transnational migration process from former Yugoslavia to Switzerland and then to Kosovo and in his attempts to realize social mobility for his children. The analysis made it possible to situate this individual narrative in its societal context and to investigate the links to sociocultural boundaries related to class, gender and ethnicity in Switzerland (for the full results cf. Ammann Dula 2019). In the next chapter, we will show some of the results. We will demonstrate how social inequalities as socio-cultural boundaries affect the possibilities of different family members to negotiate family formation and what kind of strategies they develop to cope with social inequalities.

\section{Case Study: Family Formation in a Transnational Migration Context}

Based on the results of the reconstruction of the biographies of seven members of the same family, we will reveal how social inequalities affect family formation in transnational migration context. First, we will give an overview about the family transnational migration processes. The findings are based on the analysis of biographical narrative interviews (Schütze 1983) conducted with the two parents ('father' and 'mother') and five children in one family between 2012 and 2015. With the exception of Adifete (the mother), they were conducted in German. ${ }^{3}$ The interviews have been analysed using a biographical case reconstruction method (Rosenthal 2011).

\section{Short Presentation of the Family}

We present the life courses of all the seven family members in the chronological order together to underline that the changes and decisions of family formation and migration of the different family members are interrelated. Admir (the father) and Adifete (the mother) were married in 1977 in an Albanian village in the Serbian Republic of former Yugoslavia. In the same year, their first child, Arbresha, was born. Three years later, the mother gave birth to the second daughter Blerina. One year later, in 1981, followed Clirim, their first son. In that time, Admir went temporary to Switzerland for work. Donika was born in 1984 in Switzerland, when Adifete visited Admir in Switzerland. During this period, the children stayed with their extended family in a village in former Yugoslavia. In 1986, the family obtained the right of family reunification and Adifete moved with the children to Switzerland. The children started in regular classes, despite not knowing any German. In 1987, the youngest son Egzon was born. One year after his birth, the mother Adifete started to work. The older three children, Arbresha, Blerina and Clirim finished compulsory school without gaining access to higher education. Arbresha was the only one who found a two-year apprenticeship. Blerina and Clirim started to work directly without any vocational training. In 2000, one year after the end of the war in Kosovo, Adifete moved with her youngest children, Donika and Egzon, to a big town in Kosovo (where they had not lived before). Blerina got

\footnotetext{
${ }^{3}$ For more details about the influence of the translation for the interview with the mother, see Ammann Dula 2019.
} 
married in 2002 and gave as her mother also birth to her first child in the same year. After Blerina's marriage, Admir left Switzerland and joined his wife and the youngest children in Kosovo. Clirim was the only one that stayed without being married in Switzerland.

The family tree shows the date of birth of all family members, their place of residence and their family situation at the time of the interviews.

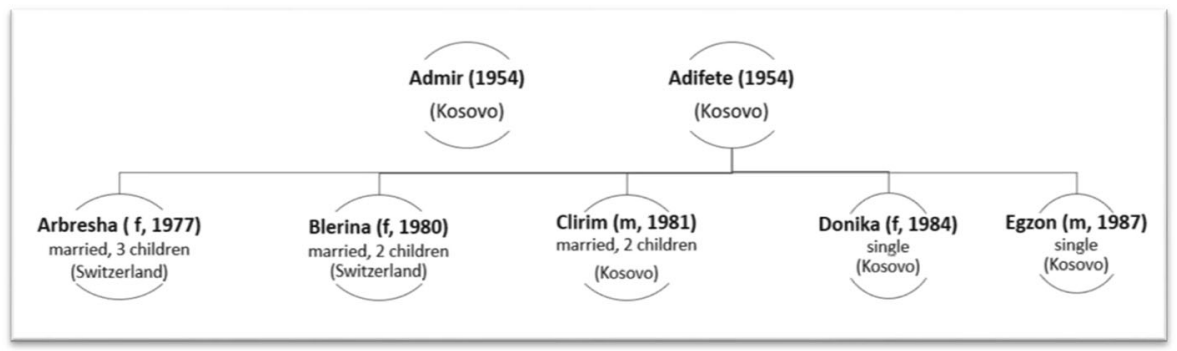

At the time of the interviews, the two youngest siblings, Donika and Egzon, are 27 and 29 years old, single and are still living with their parents in the same household in Kosovo. Clirim joined them in 2012 with his wife and the first child. All three children in Kosovo (Clirim, Donika and Egzon) have well-paid jobs despite a very high unemployment rate. The two oldest daughters, Arbresha and Blerina, remain in Switzerland. At the time of the interviews, they are married and live with their husbands and children in the neighbourhood where they grew up with their parents.

\section{Historical Background: The First Generation in Former Yugoslavia}

Adifete and Admir's families lived in villages in a rural region of former Yugoslavia that belongs today to Serbia. They lived mainly from agriculture. As Albanians living in the countryside, they had hardly no access to higher education. ${ }^{4}$ Both Adifete's and Admir's fathers founded their own families while continuing to live in the same household with their parents and the siblings. At the end of the 1960s, they migrated separately and temporarily to Germany to work and they returned only for several weeks a year to their families in their home village. At that time, seasonal work migration was quite common, as Germany was experiencing a labour shortage and actively recruited workers from the former Yugoslavia. ${ }^{5}$ Yugoslav workers were attractive as cheap labour in Western Europe, and Yugoslavians were, in turn, attracted to working in Western Europe, due to wage ratio of about 3 to 1 (Brunnbauer 2007). From 1968 to 1973, the number of Yugoslavian workers climbed from 300,000 to

\footnotetext{
${ }^{4}$ Statistics of the neighbouring province of Kosovo show that until the 1970s, many Albanian children attended only four years of primary school, even in places with schemes of eight years of primary school (Reuter 1982). However, the number of pupils of Albanian nationality is steadily rising and increased more than ten times between 1944/45 and 1970/71. But overall, Serbian and Montenegrin pupils are still overrepresented compared with their proportion of the population (Reuter 1982).

5 The recruitment of foreign workers in Germany began at the end of the 1950s. During this time, the demand for labour increased as Germany experienced the Wirtschaftswunder (the Miracle of the Rhine) while work force from East Germany was increasingly running dry due to the closure of the inner-German border (Baumann 2012).
} 
500,000. A total of around 1.1 million persons from Yugoslavia lived as 'guest workers' abroad (Calic 2014).

For the generation of the fathers, labour migration was an opportunity to earn enough money to provide financial support for the family members living in Yugoslavia (Goeke 2007). At that time, it was normal for children to remain behind. In 1970, $75 \%$ of the migrant worker children remained with relatives in Yugoslavia (Goeke 2009). Emigration was one way to gain prestige and high social status by acquiring consumer goods or building homes. Building an impressive home back in Yugoslavia demonstrated success abroad while also expressing allegiance to one's native country. One can refer to this dual attitude as transnational orientation: investing the money earned abroad to acquire social status at home. According to Brunnbauer (2009), in many rural regions, people started preferring (temporary) emigration to investment in education. In addition, migration abroad also changed the status and hierarchy structure of families in the village. Before, the families with the most land had the highest prestige. With the migration, prestige shifted to families who received income from family members abroad, although these families may have been among the poorer in the past. The migration of migrant workers also made it possible to preserve patriarchally organized extended family forms, although male family members were abroad most of the time. Especially in rural regions in the South and East, the patriarchally organized extended family remained in existence until the twentieth century (Brunnbauer 2009). This is particularly the case for the Albanian population in Yugoslavia. Many multi-generational households sent one or more sons abroad to earn money for the entire household (ibid.). Money transfers were centrally administered by the father and made it possible to avoid female employment (ibid.).

\section{Varieties of Translocational Positioning and Their Impact on the Next Generation}

The fathers found themselves in a situation of translocational positionality, i.e. a situation where there is an 'interplay of different locations relating to gender, ethnicity, race and class and their at times contradictor effects' (Anthias 2009, p. 243). They had to face different hierarchical orders regarding their social position in Germany (as lowpaid workers) and in their home village (as high-earners). The cases of the two grandfathers allow to specify the general picture about guest workers, showing the different implications the seasonal work migration had for the next generation, and the relevance of family gender norms. One instance is the way of investing social status in the home village. In Admir's family, the money earned abroad was invested in higher education: he was the first in the family to graduate from a gymnasium and went to study at a university. In the family of Adifete, the earned money was invested in the construction of new houses for every uncle, allowing the separation of the common household. The founding of a nuclear household had negative consequences for Adifete's education. At the time of her father's emigration, she dropped out after only four years out of compulsory schooling in order to support her mother at home with housework, fieldwork and childcare. The relevance of gender norms in her family becomes obvious: in contrast, her younger brother completed compulsory school and was even able to attend college afterwards and had no household responsibilities.

Admir and Adifete knew each other since their childhood. They married in 1977 and Adifete moved into Admir's' family household. Family formation had different 
implications for them: For Adifete, the marriage meant moving from her parents' home to Admir's home, a place in the neighbour village she already knew because of the common relative, and the continuity of care work. After marriage, she shared this work with her mother-in-law in the common household with her husband's younger siblings, leaving her mother and her younger siblings. As in her family, the father-in-law stayed in Germany, allowing them to live without any economic worries.

Adifete: and when I got married ((laughs)) married my husband ...the father-inlaw has also been in Germany ((we had)) also a lot of money ((laughs)) but ((it has)) been great ... my mother-in-law with me you know... my husband has three sisters and three brothers...everybody in school my husband has been in faculty you know in B....but well you know life was good..money ((but)) (2015: 189-193)

For Admir, getting married meant the return to the family in the rural context after having spent some years studying in town alone. After the marriage, for some years, he tried to combine family life in the village with studying at the University in the city. After the birth of his third child, he stopped his studies to look for work in Switzerland, taking over the role as the primary breadwinner. At that time, given the socio-economic crisis and political tensions in former Yugoslavia, a higher education, especially for the Albanian population, was no longer a guarantee of labour market success, ${ }^{6}$ so finishing University made less sense than emigration to Switzerland (Germany had at that time ceased to recruit workers from Yugoslavia ${ }^{7}$ ).

When the economic and political tension in Yugoslavia climaxed a few years later, the family accompanied the father to Switzerland. As Albanians in Yugoslavia, they were especially affected by the political and economic crisis: they were affected by discrimination processes and expulsion not only in the political sphere but also in the labour market. These socio-economic boundaries caused by class and ethnicity pushed Admir and Adifete to migrate with their children to Switzerland.

\section{Challenges of Family Formation in Switzerland}

In Switzerland, the family lived in a small town, where the two youngest children of the family (Donika and Egzon) were born. The migration of the nuclear family to Switzerland represents a first transformation of the transnational orientation and was motivated by the mother's wish to be together with her husband, living as a cohesive family.

\footnotetext{
${ }^{6}$ The crisis of the 1980s was characterised by stagnation in production and rising inflation (Roux 1992). Unemployment increased to over one million in 1984, with persons under 24 and women particularly affected (Calic 2014). According to official statistics, unemployment in the province of Kosovo in 1981 was $29 \%$ ( 90,000 job seekers), but experts estimated the figure at around 200,000 and $82 \%$ of the Albanian population (Schmitt 2008). The economic situation in the mid-1980s was very difficult, especially for the rural Albanian population who lived predominantly from subsistence farming under poor conditions (Schmitt 2008, p. 257). Due to the economic recession, most Western countries had a recruitment freeze in 1973-1974, so did Germany (Brunnbauer 2009).

${ }^{7}$ Due to the economic recession, most Western countries had recruitment freeze in 1973-1974 (Brunnbauer 2009).
} 
Adifete: you know life was good..money ((but)) children have forgotten ((their)) father..((laughs)) so or...if you have money ((you risk to)) forgot ((your)) father...((laughs)) (2015: 193-195)

In the beginning, the migration to Switzerland leads to a social decline, reinforced by socio-cultural boundary processes due to class and ethnicity. Despite the father's university studies in former Yugoslavia, in Switzerland, he was considered an unqualified worker and earned barely enough to feed the family of seven, and so the mother began working in a factory as well. The mother directly addressed this social degradation talking about the financial precariousness in Switzerland despite her additional income through her work in a factory.

Adifete: if I worked early shift I had to start at five o'clock in the morning until half past two...when I worked late shift then I started at half past two until half past eleven...I worked..but it has been good..work but money we have taken..heavy work but you have to.. if you have children and only one payday is tight (2015: 482-485)

Her case also reveals the importance of gender for socio-cultural boundaries in Switzerland. She faced three-fold socialization ${ }^{9}$ (Lenz 1996) in Switzerland. As the mother of five children, wife of a 'guest worker', with limited primary school education, a foreigner and as part of a migration minority, her possibilities to combine gainful employment with her role as a mother and to participate in social life and learn the local language were limited. At this time, in the countryside, the possibilities to learn the local language were limited, especially for adults. As the following citation illustrates, this situation, especially not speaking the local language, limited her independence and autonomy compared with her home village.

Adifete: and then at home when it rings at the front door you know... ciao welcome ((laughs)) I can't talk you know.. what to say..when the post arrives you have talk..uhh ..shall I sign or shall I not sign (2015: 1104-1107)

This shows that for her, migration to Switzerland was associated with a loss of autonomy. However, she did not learn the language, even when the children started to speak Swiss German among themselves. This can be considered as an indicator for her ongoing transnational orientation influenced by the experienced socio-cultural boundaries. In contrast, her husband Admir tried a local orientation by gaining social

\footnotetext{
$\overline{8}$ The interviews were conducted in German and transcribed literally. For this publication, they were translated into English and edited for the ease of reading.

9 According to Lenz (1996), this situation can be described as 'threefold socialization' (dreifache Vergesellschaftung) in a gendered relationship. Lenz describes the family or the household and the associated neo-patriarchal division of labour as the first level of socialization (ibid.), the second level as the labour force in the capitalist labour market, which in Adifete's situation shows itself as an unqualified labour force in a company in the low-wage sector. The third level represents the modern nation state, as political socialization, citizenship and political participation (ibid.).
} 
status in Switzerland, in part by buying an apartment in a small town with more schooling and work opportunities.

\section{Intergenerational Transmission: The Relevance of Social Inequalities for the Next Generation}

However, the entrance of the mother into the labour market has also some negative implication for the older two daughters. The lack of child care facilities in the countryside and the absence of family networks meant her daughters had to take over childcare. At the age of 10, Arbresha, the oldest daughter, took over the role of taking care for her younger siblings Donika and Egzon (one-year old). As the following quote illustrates, she began to raise him as her own:

Arbresha: my mother still there in the night she has worked so late shift at five o'clock in the evening she has gone I have the Egzon a little (baby) have to take care in the evening we have always had to watch him there he has been such a small baby such a fat and yes ... there we have been also still in Z. and I have ... so he is my brother and somehow like my child (2012: 158-162)

Taking on the responsibility of caring for younger siblings limited Arbresha's and Blerina's educational possibilities. When Arbresha finished compulsory education, she started an apprenticeship in a nearby shopping mall, contributing to the family income. Her sister Blerina had then to take over her job in the household looking after the younger siblings. Blerina then entered the labour market without any vocational training. The case studies of the two daughters show that the socio-cultural boundaries that the family experienced in Switzerland due to its low social status (unqualified workers) and the difficulty of reconciling work and childcare lead the tradition of family gender norms (transmission of care work to the daughters and limitation of educational possibilities).

However, the difficulties of obtaining educational qualifications and entering the job market are not only linked to the transmission of care and family gender norms, as shown in their brother Clirim's case. Although he graduated from secondary school, he started working without any qualifications in the same enterprise (Swisswell) as his father. His case illustrates that discrimination processes due to ethnicity and class have an impact of family formation.

Clirim: and I was the only one of the class who didn't do an apprenticeship and somehow already went to work at Swisswell (2013a: 1117-1119)

Clirim was not limited by gender or household responsibilities, but he also failed to attain any education beyond compulsory schooling-presumably a combination of poor grades, discrimination and a lack of social networks - factors that have all been shown to limit migrant youth (Haeberlin, Imdorf and Kronig 2004). These studies also point out that a limited network is one reason for foreign youths to be discriminated when looking for a training place (ibid.). This shows the interwoven relevance of 
ethnicity, gender and class for the three siblings when entering the labour market that leads to a transmission of the parents' status as unqualified workers in Switzerland.

In this situation, the father and the mother return to the strategy of transnational orientation, which is reflected in their property investment in Kosovo. They bought land in Kosovo even before the war in a time of socio-economic tensions, in a place they had never lived, and constructed a house. In 2000, one year after the war ended in Kosovo, the mother moved with the two youngest children (Donika and Egzon) to Kosovo in the hope of providing their children with better educational and employment opportunities. This enabled them to use migration again to overcome socio-cultural boundaries they met in Switzerland, limiting their, especially their children's, possibilities of social advancement through education or in the labour market. The migration to Kosovo ultimately enabled them to realize social mobility for themselves and their children: the two youngest children gain access to further education in Kosovo.

The cases of Admir and Adifete show that the transnational migration pathway is highly motivated by their aspiration to social advancement and a way of overcoming the experienced socio-cultural boundaries.

\section{Transnational Family Negotiations}

The migration back to Kosovo not only provided social mobility for the younger children but also impacted family formation for the older children. Blerina stayed after the migration of her mother and siblings in the same household with her brother Clirim and her father, taking over caring functions in the household in addition to her full-time employment as Arbresha was at that moment already married and lived in her own apartment with her husband and child. After migration, the mother looked for a suitable husband in Kosovo for her daughter Blerina. Blerina travelled to Kosovo to meet this man and after some hesitation agreed to get married under the condition that she could stay in Switzerland. After the marriage, her husband came to Switzerland and they moved into an apartment for themselves. At the same time, her father left Switzerland and moved to her mother and younger siblings. As in her mother's case, Blerina never had a period in her life when she was not caring for a household. However, for her, it was very important not to have the responsibility to take care of the extended family as the following citations shows:

Blerina: I have the mother-in-law then you stand up you don't know you clean the whole day there clean there ... and make coffee tea food no that's not for me now ... I have to do it here ((in Switzerland)) also I have to clean here also to make food but it's all different to do it for your own family.. there ((in Kosovo)) you have to do it for 20 people it's a little bit..yes awkward and yes ... and everyone has their own desires and you do not know what and then you must there ((in Kosovo)) I have not been able to imagine that ... and then you think for your children you do not want everyone in the house there a lifelong ... and there ((in Kosovo)) you cannot change it (2012: 342-349)

Blerina presents Kosovo as a country in which the patrilocal traditions are not negotiable and in which she would have to assume the traditional role of a 
woman in the family of her parents-in-law. In return, she points out that Switzerland offers her more freedom, as she has to manage the household only for the nuclear family while at the same time being able to work. With her clear decision against living in Kosovo, Blerina shows that she rejects the traditional role of daughter-in-law. Blerina's case illustrates the possibility of negotiating family gender norms in a transnational context. Staying in Switzerland is a form of distancing herself from the family-in-law and its gender norms.

\section{Family Formation as a Strategy to Overcome Sociocultural Boundaries}

After the parents left Switzerland and moved to Kosovo with the youngest children, Clirim and his older sisters (Arbresha and Blerina) remain in Switzerland. After Blerinas marriage and the emigration of his father, Clirim lived alone. His two sisters lived with their own families in the neighbourhood. He quit his job and for several years, he enjoyed 'making party', living in a financial precarious situation. In the following, he compares life before and after marriage.

Clirim: I just wanted to make party..the parents are here ((in Kosovo)) and there ((in Switzerland)) has been the time when I told myself..so Clirim.. now you have just to enjoy life..because I knew the times comes to get married and so and I do not want to do that ((enjoying life)) after I got married (2013a: 1195-1199)

He links the time of 'enjoying life' with having no professional ambitions before founding a family. He started to look for a job only when he got engaged with a woman in Kosovo. Following the engagement, he travelled back and forth between Kosovo and Switzerland, looking for a permanent job in Switzerland.

Clirim: and then when I got engaged to the wife it started again and again I worked there and then there again and again and it didn't work out that way.. just two three months somewhere and then I let it go again... I came down ((to Kosovo)) for a few months I came up ((to Switzerland)) again... and that has always been such a dilemma yes and I didn't know should I take my wife up there ((Kosovo)) ... live there.. or come down here ((Switzerland)) (2012: 295-300)

His difficulties finding a job in Switzerland increased his indecisiveness about to stay in Switzerland or to move to Kosovo. Finding a stable job was also a key criterion for obtaining a residency permit for his wife. This shows that his decision whether to stay in Switzerland or to move to Kosovo is limited both by Swiss migration policy and by socio-cultural boundary processes in Switzerland: As an unqualified, foreign man, it was difficult for him to find a job after a long period of unemployment. Eventually, he chose to leave Switzerland after the birth of his first child, moving into the household with his parents in Kosovo. In part, this decision was based on wanting to be close to family to care for his child. 
Clirim: then my wife got pregnant and then I told myself now I'm going back ((to Kosovo))..just because I know how it is in Switzerland..to get up early in the morning and put the child in the hand of a stranger.. and I said for me no.. here ((in Kosovo)) are my parents and my child is at home and yes..since then I'm here (2013a: 1272-1276)

Migrating to Kosovo enables him to overcome the precarious working situation in Switzerland and at the same time brings him closer to his family. Although family support for childcare was the primary reason to migrate to Kosovo, his family networks also improved his labour market position. His younger sister helped him find a job in a big company, allowing him to take over the role as a breadwinner for his family. Linking professional ambitions with the orientation on family gender norms allowed him to overcome his precarious work situation in Switzerland and to fulfil the role as the breadwinner in Kosovo. Clirim's case shows that migration systems and sociocultural boundaries limit the possibilities of family formation in Switzerland and lead to an intergenerational transmission of family gender norms as Clirim continued in the role as a breadwinner, staying with his parents in the same household in Kosovo.

\section{Conclusions}

Overall, the case reconstruction of members of two generations of one family made it possible to reconstruct the continuity and changes of family formation over generations in a transnational migration context. The comparative analysis of the members of this family shows the relevance of social inequalities in different context and their strategies to use a transnational orientation to negotiate family gender norms or realising social mobility. The presented results demonstrate not only the relevance of socio-cultural boundaries for family formation, linked to hierarchisation processes based on class and ethnicity, but also the relevance of gender and migration policies.

\section{The Relevance of Social Inequalities for Family Formation in an Intergenerational Comparison}

In the selected family, all generations were affected by socio-cultural boundary processes either in Yugoslavia or Switzerland, based on the categories class and ethnicity that motivated the transnational migration processes. In former Yugoslavia, as Albanians, their attempts to realise social mobility were limited. In the generation of the parents, economic crisis and political tensions in former Yugoslavia in the 1980s led to a devaluation of education and increasing unemployment for the Albanian minority. Fulfilling family gender norms, especially for men, taking over the role as a breadwinner of the family, became difficult. Seasonal migration linked to a transnational orientation thus became a strategy for multiple generations to deal with social inequalities.

In Switzerland, again socio-cultural boundary processes based on ethnicity and class affected the parents' attempts to gain social status in Switzerland by acquiring property and attempting to invest in education for their children. As foreigners from former Yugoslavia and unqualified workers, they were situated on the leader of social 
hierarchy and had an impact for the next generation. Despite their efforts, their children held the same low social status as unqualified workers, partly due to discrimination in education and in the labour market. This motivated the parents to ultimately leave Switzerland when the situation in their origin region stabilized, as their younger children had better educational opportunities in Kosovo.

\section{The Relevance of Socio-cultural Boundaries for the Transmission of Family Gender Norms}

The experienced socio-cultural boundaries in former Yugoslavia and in Switzerland strengthen the transmission of family gender norms and limit the possibility to negotiate family formation. In Switzerland, economic constraints and the absence of childcare facilities led to the transmission of care work from Adifete to her daughters and a limitation of their educational pathway and in doing so, a transmission of gender norms to the next generation. In Clirim's case, his precarious work and financial situation, influenced by discrimination processes in education and the labour market, limited his possibility to continue to live an independent life in Switzerland. Restriction in migration policies lead to the founding of his own family in the same household with his parents in Kosovo.

\section{The Relevance of Migration Policies for Family Formation in a Transnational Migration Context}

For the grandfathers, being citizens of Yugoslavia allowed them to use migration as a strategy of upward social mobility in their home village, fulfilling their role as breadwinners. Admir took over the transnational positioning in a situation of growing socio-cultural boundaries in Yugoslavia before moving with his family to Switzerland. Adifete continued this transnational orientation in Switzerland due to the experienced socio-cultural boundaries. The situation changed for the next generation. Since 1990, former Yugoslavia is considered as a 'third country' and migration is limited to high-skilled migrants and family reunification. Clirim experienced the consequences of this new situation. The need to prove a successful integration into the labour market and enough financial means as condition for family reunification is limiting the possibilities of family formation, especially for those non-EU citizens experiencing already socio-cultural boundaries on the labour market in Switzerland.

The different strategies of family formation of the members of the same family demonstrate the relevance of access to educational institutions, the position on the labour market and migration policies for the ability to negotiate family formation and family gender norms. The family members compare their position in a transnational context, considering their different possibilities of social mobility, and also the different gender norms (Blerina) and possibility of combining childcare and employment (Clirim) in the relevant contexts. In this way, it could be shown how family members use their knowledge of context-specific hierarchies to position themselves transnationally or locally, also negotiating gender roles and child care responsibilities. At the same time, socio-cultural boundary processes and migration regimes can also limit the family formation possibilities, as the example of Clirim illustrates. 
Nevertheless, the selected cases are showing the gaining importance of family to overcome boundaries and borders leading to a transmission of family gender norms.

By applying a reconstructive biographical analysis in combination with the analytical concept of socio-cultural boundaries, it was possible to demonstrate the diversity of strategies in the interwoven social context between former Yugoslavia, Switzerland and Kosovo. This methodological approach made it possible to analyse the connection between social hierarchisation processes in different contexts and thus to point out the translocational positioning of the different family members as a strategy of dealing with context-specific socio-cultural boundary processes. The case study demonstrates the relevance of taking into consideration processes of social inequalities that are performed in a transnational context. It became apparent that the different strategies of negotiating family are related to migration experiences and encompass several generations. These individual negotiation processes and ways of family formation also represent an interaction with context-specific socio-cultural boundaries that can change over time and take place across borders. This allows to discover differences not only between and inside migration minorities but also within families. Family members can develop various strategies to deal with social inequalities, developing a kind of transnational positionality and comparing their possibilities in a transnational context. Considering several generations and different members of one family can be fruitful when attempting to understand the complexity of family practices in interaction with social inequalities.

Acknowledgements Open access funding provided by Bern University of Applied Sciences.

Open Access This article is licensed under a Creative Commons Attribution 4.0 International License, which permits use, sharing, adaptation, distribution and reproduction in any medium or format, as long as you give appropriate credit to the original author(s) and the source, provide a link to the Creative Commons licence, and indicate if changes were made. The images or other third party material in this article are included in the article's Creative Commons licence, unless indicated otherwise in a credit line to the material. If material is not included in the article's Creative Commons licence and your intended use is not permitted by statutory regulation or exceeds the permitted use, you will need to obtain permission directly from the copyright holder. To view a copy of this licence, visit http://creativecommons.org/licenses/by/4.0/.

\section{References}

Amelina, A. (2012). Socio-spatial scales as social boundaries? Or: How do migration studies profit from including "space" in the sociology of social boundaries. Migration Letters, 9(3), 273-288.

Amelina, A. (2017). Transnationalizing inequalities in Europe, sociocultural boundaries, assemblages and regimes of intersection. New York/London: Routledge.

Ammann Dula, E. (2018). Intersektionalität als soziokulturelle Grenzziehungsprozesse in der Biographieforschung. Am Beispiel der biographieanalytischen Untersuchung des transnationalen Migrationsprozesses einer Familie aus dem ehemaligen Jugoslawien. In H. Dierckx, D. Wagner, \& S. Jakob (Eds.), Intersektionalität und Biografie. Interdisziplinäre Zugänge zu Theorie, Methode und Forschung (pp. 121-138). Barbara Budrich: Opladen/Berlin/Toronto.

Ammann Dula, E. (2019). Familie transnational. Eine biographieanalytische Studie einer Familie aus dem ehemaligen Jugoslawien. Bielefeld: transcript.

Anthias, F. (2001). The material and the symbolic in theorizing social stratification: issues of gender, ethnicity and class. The British Journal of Sociology, 52(3), 367-390. https://doi.org/10.1080 /00071310120071106. 
Anthias, F. (2009). Intersectionality, belonging and translocational positionality, thinking about transnational identities. In G. Rosenthal \& A. Bogner (Eds.), Ethnicity, belonging and biography. Ethnographical and biographical perspectives (pp. 229-250). Berlin: LIT Verlag.

Apitzsch, U. (2003). Migrationsbiographien als Orte transnationaler Räume. In U. Apitzsch \& M. M. Jansen (Eds.), Migration, Biographie und Geschlechterverhältnisse (pp. 65-80). Münster: Westfälisches Dampfboot.

Baldassar, L., \& Merla, L. (2014). Transnational families, migration and the circulation of care, understanding mobility and absence in family life. New York: Routledge.

Baumann, A.-L. (2012). Soziale Mobilität in der Einwanderergruppe der ehemaligen Gastarbeiter - Intragenerationale Lebenslaufdynamiken. In P. Pielage, L. Pries, \& G. Schultze (Eds.), Soziale Ungleichheit in der Einwanderungsgesellschaft, Kategorien, Konzepte, Einflussfaktoren (pp. 138-153). Bonn: FriedrichEbert-Stiftung.

Bauschke-Urban, C. (2010). Im transit. Transnationalisierungsprozesse in der Wissenschaft. Wiesbaden: VS Verlag.

Brunnbauer, U. (2007). Jugoslawische Geschichte als Migrationsgeschichte (19. und 20. Jahrhundert). In Brunnbauer Ulf, Helmedach, Andreas und Troebst Stefan (Ed.), Schnittstellen, Gesellschaft, Nation, Konflikt und Erinnerung in Südosteuropa (pp. 111-132). München: R. Oldenbourg Verlag.

Brunnbauer, U. (2009). Labour emigration from the Yugoslav region from the late 19th century until the end of socialism: Continuities and changes. In U. Brunnbauer (Ed.), Transnational societies, transterritorial politics. Migrations in the (post)Yugoslav region, 19th - 21th century (pp. 17-49). Oldenbourg Verlag: München.

Burri Sharani, B., Efionayi-Mäder, D., Hammer, S., Pecoraro, M., Soland, B., Tsaka, A. \& Wyssmüller, C. (2010). Die kosovarische Bevölkerung in der Schweiz. Bern: Bundesamt für Migration.

Calic, M.-J. (2014). Geschichte Jugoslawiens im 20. Jahrhundert, $2^{\text {nd }}$ edn., München: C. H. Beck Verlag.

Dahinden, J. (2014). Kulturals Form symbolischer Gewalt: Grenzziehungsprozesse im Kontext von Migration am Beispiel der Schweiz. In B. Nieswand \& H. Drotbohm (Eds.), Kultur, Gesellschaft, Migration. Studien zur Migrations- und Integrationspolitik (pp. 97-121). Springer VS: Wiesbaden.

Dausien, B. (2008): Biographieforschung: Theoretische Perspektiven und methodologische Konzepte für eine re-konstruktive Geschlechterforschung, In Ruth Becker \& Beate Kortendiek (Ed.), Handbuch Frauenund Geschlechterforschung (pp. 354-367). 2nd edn. Wiesbaden: VS Verlag.

Duemmler, K. (2015). Symbolische Grenzen. Zur Reproduktion sozialer Ungleichheit durch ethnische und religiöse Zuschreibungen. Bielefeld: transcript Verlag.

Duemmler, K., Dahinden, J., \& Moret, J. (2010). Gender equality as 'cultural stuff': ethnic boundary work in a classroom in Switzerland. Diversities, 12(1), 19-37.

Fibbi, R., Wanner, P., Topgül C. \& Urgina, D. (2015). The new second generation in Switzerland. Youth of Turkish and Former Yugoslav Descent in Zürich and Basel. Amsterdam: University Press.

Fouron, G. \& Glick Schiller, N. (2001). All in the family: Gender, Transnational Migration, and the Nation State. Identities, 7, 539-582. https://doi.org/10.1080/1070289X.2001.9962678.

Geisen, T. (2014). Multilokale Existenzweisen von Familien im Kontext von Migration. Herausforderungen für Forschung und Theorieentwicklung. In T. Geisen (Ed.), Migration, Familie und Gesellschaft (pp. 2758). Wiesbaden: Springer Verlag.

Goeke, P. (2007). Transnationale Migrationen. Post-jugoslawische Biografien in der Weltgesellschaft. Bielefeld: transcript Verlag.

Goeke, P. (2009): From Ubiquitous to Specific Networks. Social Change and the Relevance of Networks in Migrant Families. In Ulf Brunnbauer (Ed.), Transnational Societies, Transterritorial Politics, Migration in the (Post)Yugoslaw Region 19th - 21th century (pp.283-298). München: Oldenbourg Verlag.

Haeberlin, U., Imdorf, C., \& Kronig, W. (2004). Chancenungleichheit bei der Lehrstellensuche. Der Einfluss von Schule, Herkunft und Geschlecht. Bern/Aarau: Schweizerischer Nationalfonds.

Kofman, E., Kraler, A., Kohli, M., \& Schmoll, C. (2011). Introduction: issues and debates on family-related migration and the migrant family: a European perspective. In A. Kraler, E. Kofman, M. Kohli, \& C. Schmoll (Eds.), Gender, generations and the family in international migration (pp. 13-54). Amsterdam: University Press.

Lamont, M., \& Molnar, V. (2002). The study of boundaries in the social sciences. Annual Review of Sociology, 28, 167-195. https://doi.org/10.1146/annurev.soc.28.110601.141107.

Lenz, I. (1996). Grenzziehungen und Öffnungen: Zum Verhältnis von Geschlecht und Ethnizität zu Zeiten der Globalisierung. In I. Lenz \& A. Germer (Eds.), Wechselnde Blicke. Frauenforschung in internationaler Perspektive (pp. 200-228). Leske + Budrich: Opladen. 
Lutz, H. (2004). Transnationale Biographien in globalisierten Gesellschaften. In M. Ottersbach \& E. Yildiz (Eds.), Migration in der metropolitanen Gesellschaft. Zwischen Ethnisierung und globaler Neuorientierung (pp. 207-216). LIT Verlag: Münster.

Lutz, Helma (2014). Intersectionality's (brilliant) career - how to understand the attraction of the concept? In Working Paper Series "Gender, Diversity and Migration”, 1, http://www.fb03.uni-frankfurt. de/51634119/Lutz_WP.pdf. Accessed 2 April 2020.

Lutz, H., \& Schwalgin, S. (2006). Globalisierte Biographien: Das Beispiel einer Haushaltsarbeiterin. In W.-D. Bukow, M. Ottersbach, E. Tuider, \& E. Yildiz (Eds.), Biographische Konstruktionen im multikulturellen Bildungsprozess. Individuelle Standortsicherung im globalisierten Alltag (pp. 99-113). VS Verlag für Sozialwissenschaften: Wiesbaden.

Mahler, S. J., \& Pessar, P. R. (2001). Gendered geographies of power: analyzing gender across transnational spaces. Identities, 7(4), 441-459.

Mau, S. (2007). Transnationale Vergesellschaftung, Die Entgrenzung sozialer Lebenswelten. Frankfurt/New York: Campus Verlag.

Pachucki, M. A., Pendergrass, S., \& Lamont, M. (2007). Boundary processes: recent theoretical developments and new contributions. Poetics, 35(6), 331-351. https://doi.org/10.1016/j.poetic.2007.10.001.

Piguet, E. (2006). Einwanderungsland Schweiz. Bern: Haupt Verlag.

Pries, L. (2010). Transnationalisierung. Theorie und Empirie grenzüber-schreitender Vergesellschaftung. Wiesbaden: VS Verlag.

Randeria, S. \& Römhild, R. (2013). Das postkoloniale Europa: Verflochtene Genealogien der Gegenwart. Einleitung zur erweiterten Neuauflage. In Sebastian Conrad, Shalini Randeria \& Römhild, Regina (Ed.), Jenseits des Eurozentrismus. Postkoloniale Perspektiven in den Geschichts- und Kulturwissenschaften (pp. 9-31). $2^{\text {nd }}$ edn. Frankfurt: Campus Verlag.

Reuter, J. (1982). Die Albaner in Jugoslawien. München: R. Oldenbourg Verlag.

Rosenthal, G. (2011). Interpretative Sozialforschung. Eine Einführung (3nd ed.). Weinheim/München: Juventa Verlag.

Roux, M. (1992). Les albanais en Yougoslavie, minorité nationale, territoire et développement. Paris : éditions de la maison des sciences de l'homme.

Ruokonen-Engler, M.-K. (2012) Unsichtbare“ Migration? Transnationale Positionierungen finnischer Migrantinnen. Eine biographieanalytische Studie. Bielefeld: transcript Verlag.

Schmitt, O. J. (2008). Kosovo, Kurze Geschichte einer zentralbalkanischen Landschaft. Wien: Böhlau Verlag.

Schnell, P. \& Fibbi, R. (2015). Getting ahead through various avenues: examining educational and occupational pathways of the 'new' second-generation in Switzerland. Journal of International Migration and Integration. https://doi.org/10.1007/s12134-015-0452-y.

Schütze, F. (1983). Biographieforschung und narratives interview. Neue Praxis, 13(3), 283-293.

Siouti, I. (2013). Transnationale Biographien. Eine biographieanalytische Studie über Transmigrationsprozesse bei der Nachfolgegeneration griechischer Arbeitsmigranten. Bielefeld: transcript Verlag.

Tuider, E. (2011). "Sitting at a Crossroad" methodisch einholen. Intersektionalität in der Perspektive der Biographieforschung. In Sabine Hess, Nikola Langreiter \& Elisabeth Timm (Ed.), Intersektionalität revistited. Empirische, theoretische und methodische Erkundungen (pp. 221-245). Bielefeld: transcript Verlag.

Wimmer, A., \& Glick Schiller, N. (2002). Methodological nationalism and beyond: nation-state building, migration and the social sciences. Global Networks, 2(4), 301-334.

Publisher's Note Springer Nature remains neutral with regard to jurisdictional claims in published maps and institutional affiliations. 